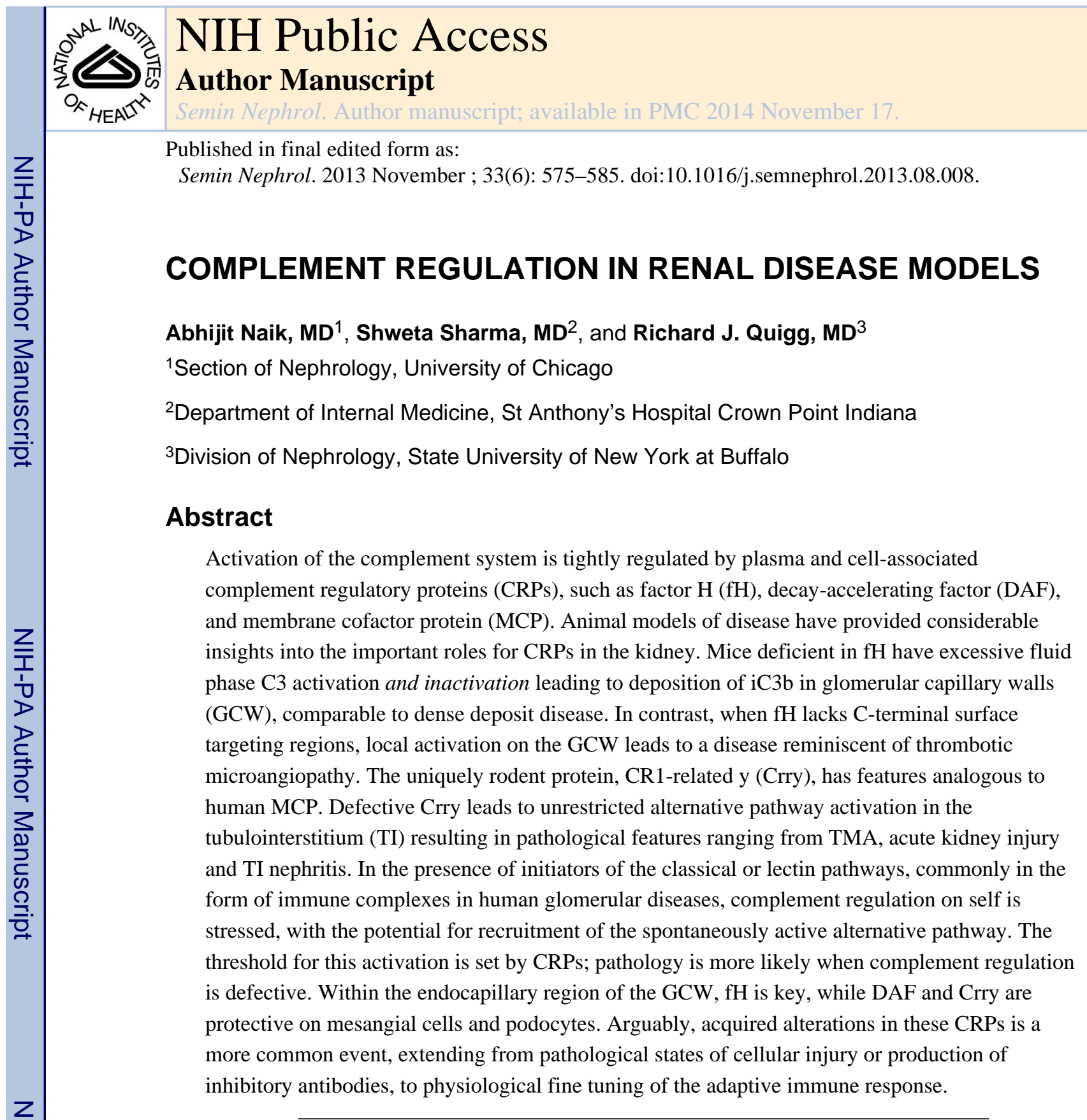

Activation through classical, alternative or lectin complement pathways leads to the cleavage of C3 and C5 and generation of C3a, C3b, C5a and C5b. The latter can combine with $\mathrm{C} 6, \mathrm{C} 7, \mathrm{C} 8$ and $\mathrm{C} 9$ to form $\mathrm{C} 5 \mathrm{~b}-9$ in any receptive cell membrane; although this is fairly promiscuous, the effects of such C5b-9 formation appear to have some specificity in terms of cellular pathways that become activated (see chapter 9 , this issue). ${ }^{1-3}$ In contrast, $\mathrm{C} 3 \mathrm{a}, \mathrm{C} 3 \mathrm{~b}$ and C5a have specific cellular and plasma protein ligands. Anaphylatoxin

\footnotetext{
(C) 2013 Elsevier Inc. All rights reserved.

Corresponding Author: Richard J. Quigg, MD, Arthur M. Morris Professor of Medicine, State University at Buffalo School of Medicine and Biomedical Sciences, 875 Ellicott Street, 8022AA, Buffalo, New York 14203, rquigg@buffalo.edu. Disclosures: AN, SS and RJQ have nothing to disclose.

Publisher's Disclaimer: This is a PDF file of an unedited manuscript that has been accepted for publication. As a service to our customers we are providing this early version of the manuscript. The manuscript will undergo copyediting, typesetting, and review of the resulting proof before it is published in its final citable form. Please note that during the production process errors may be discovered which could affect the content, and all legal disclaimers that apply to the journal pertain.
} 
receptors $\mathrm{C} 3 \mathrm{aR}$ and $\mathrm{C} 5 \mathrm{aR}(\mathrm{CD} 88)$ are in the rhodopsin family of seven-span transmembrane proteins. C3b-binding proteins include the regulators of complement activation (RCA) proteins (discussed below), and $\beta_{2}$ integrin (CD18) heterodimers with $a_{M}$ (Itgam, CD11b) and $\mathrm{a}_{\mathrm{x}}$ (Itgax, CD11c), also termed complement receptors 3 and 4 (CR3 and CR4) because they bind $\mathrm{C} 3 \mathrm{~b}$ products. $\mathrm{C} 3 \mathrm{aR}$ and $\mathrm{C} 5 \mathrm{aR}$ couple to G-proteins to transduce their signals, while the $\beta_{2}$ integrins may generate outside-in signals via immunoreceptor tyrosine-based activation motif proteins and spleen tyrosine kinase. Despite the limited ligand-receptor systems, the net effect of complement activation can vary considerably depending on the context.

The vestiges of the alternative complement pathway were present one billion years ago in sea anemones of the phylum Cnidaria. Over time, genome, chromosome and individual gene duplications have resulted in over 40 complement genes in higher vertebrates. ${ }^{4 ; 5}$ It is presumed that evolutionary pressure from infectious microorganisms led to an increasingly active complement system. The benefits of this protective system were limited by the negative effects of complement activating on self tissues, which led to the evolution of a multitude of regulatory checkpoints. There is considerable genetic, structural and functional variability within the complement system proteins. ${ }^{6 ; 7}$ This level of complexity is very relevant when considering the mechanics of complement activation; for example, antibodymediated complement activation beginning with the classical pathway, recruiting the alternative pathway, and ending in the terminal pathway, requires 14 activating proteins, and can be affected by 11 regulatory proteins (Figure 1). This has led Harris, de Cordoba and Morgan to propose the term "complotype" as reflecting the pattern of genetic variants in complement genes inherited by an individual, which alters risk for both inflammatory disorders and infectious diseases involving complement. ${ }^{8}$

\section{COMPLEMENT REGULATION}

The complement system is heavily regulated, including by time and space; several complement intermediates have little time to find particular acceptor sites before inactivation. For example, in the fluid phase, the exposed thioester in $\mathrm{C} 4 \mathrm{~b}$ and $\mathrm{C} 3 \mathrm{~b}$ must find a receptive carbohydrate or amino group within $0.1 \mathrm{~s}$ before inactivation (i) by hydrolysis. ${ }^{9}$ Similar constraints occur upon formation of the trimolecular C5b-7 complex, in which the exposed hydrophobic domain must find an acceptor lipid membrane in approximately $0.1 \mathrm{~s} .^{10}$

There are also dedicated complement regulatory proteins (CRPs), the majority of which block $\mathrm{C} 3$ and/or $\mathrm{C} 5$ activation, presumably reflecting the importance of their activation. ${ }^{11}$ These are the RCA family members, $\mathrm{C} 4$ binding protein ( $\mathrm{C} 4 \mathrm{bp}$ ), factor $\mathrm{H}(\mathrm{fH})$, decayaccelerating factor (DAF, CD55), membrane cofactor protein (MCP, CD46), complement receptors 1 and 2 (CR1 and CR2), and the rodent specific CR1-related y (Crry). Proteins which prevent formation of $\mathrm{C} 5 \mathrm{~b}-9$ include plasma clusterin and $\mathrm{S}$ protein, and cellular CD59. The complement inhibitory properties of all these CRPs are conferred by their fairly low affinity binding for $\mathrm{C} 3, \mathrm{C} 4$ and/or $\mathrm{C} 5$ products. 
In contrast, the plasma proteins, factor I (fI) and carboxypeptidase N (CPN) structurally inactivate complement intermediates, $\mathrm{C} 3 \mathrm{~b}$ and $\mathrm{C} 4 \mathrm{~b}$, and $\mathrm{C} 3 \mathrm{a}$ and $\mathrm{C} 5 \mathrm{a}$, respectively. ${ }^{11}$ Here again the importance of the $\mathrm{C} 3 / \mathrm{C} 5$ step is evident. Both are produced in their active forms; fI requires a cofactor from among $\mathrm{C} 4 \mathrm{bp}, \mathrm{fH}, \mathrm{MCP}, \mathrm{CR} 1$, or Crry, which facilitates fI binding and also allows full expression of its catalytic domain. ${ }^{12}$

In a physiological sense, the distinction between complement regulation and its activation is exploited by the adaptive immune system by utilizing C3/C5-binding proteins on lymphocytes and dendritic cells (DCs). For example, the B lymphocyte signaling complex contains CR2, which can be activated by immune complexes (ICs) containing natural antibody, foreign antigen, and activated C3, thereby facilitating an adaptive humoral response to that antigen. ${ }^{13}$ More recent evidence has shown complement impacts cellular immunity (covered in detail in Chapter 7 in this issue). Here, it appears the T cell and its antigen-presenting DC partner both generate complement proteins and downregulate DAF, the net result being local complement activation. Signals through C3aR and C5aR affect $\mathrm{T}$ cell proliferation and differentiation in normal $\mathrm{T}$ cell responses, as well in autoimmunity and alloimmunity. ${ }^{14-18}$ The relevance of these largely in vitro observations has held up in correlative human studies. ${ }^{19 ; 20}$

All RCA proteins are composed of short consensus repeat (SCR) domains of $\sim 60$ amino acids, and are highly related within and between even distant species. ${ }^{21-23}$ Human, mouse and rat $\mathrm{fH}$ are very similar, containing solely 20 SCRs arranged in tandem. ${ }^{24-26} \mathrm{DAF}$ and MCP each have only 4 SCRs along with membrane proximal O-glycosylated regions. DAF is linked to the plasma membrane through a glycosylphosphatidylinosoitol (GPI) anchor, while MCP is a type I transmembrane protein. Although mouse Crry was first discovered with a human $C R I$ cDNA probe (giving rise to its unique name), it is a short transmembrane protein most similar to MCP. ${ }^{27-29}$

The functional activities of each RCA family member are attributable to their binding to C3 products, with the exception of $\mathrm{C} 4 \mathrm{bp}$ which has limited binding to $\mathrm{C} 3 \mathrm{~b}$ in physiological conditions. Most other RCA members can also bind $\mathrm{C} 4 \mathrm{~b}$, which expands their repertoire to classical and lectin pathway $\mathrm{C} 3$ convertases. Importantly for some of the conclusions reached to-date, $\mathrm{fH}$ is not a $\mathrm{C} 4 \mathrm{~b}$-binding protein, and is therefore limited to inhibiting the formation and accelerating the decay of intermediates with $\mathrm{C} 3 \mathrm{~b}$. Factor $\mathrm{H}$ does serve as cofactor for fI-mediated cleavage and inactivation of $\mathrm{C} 3 \mathrm{~b}$ to iC $3 \mathrm{~b}$ (to be distinguished from C3bi occurring from hydrolysis of C3b) ${ }^{30}$ In spite of their similar SCR compositions, DAF, $\mathrm{MCP}$ and Crry have distinct functions as complement regulators. DAF has decayaccelerating activity towards $\mathrm{C} 3$ and $\mathrm{C} 5$ convertases of all pathways, while MCP is a fIcofactor only. Interestingly, Crry has the features of DAF and MCP, and hence is a versatile and potent complement regulator. ${ }^{31}$

Factor $\mathrm{H}$ is produced primarily in the liver and circulates in human and rodent plasma at relatively high concentrations $(\sim 500 \mu \mathrm{g} / \mathrm{ml}$ or $3.3 \mathrm{mmol} / \mathrm{L}),{ }^{26 ; 32}$ a fact underlying attempts at liver transplantation to treat genetic $f H$ defects. ${ }^{33}$ Although there is evidence for $\mathrm{fH}$ production by other cells of the mononuclear phagocyte lineage, bone marrow-derived cells do not contribute substantially to the circulating $\mathrm{fH}$ pool. ${ }^{34 ; 35}$ 
DAF, MCP and Crry protect the kidney from complement activation. Each of these proteins tend to have their distinct localization patterns by immunohistochemical techniques. In humans, MCP appears to be fairly uniformly distributed in all three intrinsic glomerular cells, ${ }^{36 ; 37}$ while DAF is highly expressed in the juxtaglomerular apparatus. ${ }^{38}$ Functional DAF is also on cultured human podocytes, ${ }^{39}$ which is relevant to studies with rodent podocyte DAF (discussed below). Other sites in human kidneys served by DAF and/or MCP include endothelial and tubular cells. ${ }^{37}$

Complement regulatory proteins have evolved somewhat differently in rodents, yet perform nearly identical functions to those in humans. In rodent kidneys, DAF is primarily a podocyte and vascular endothelium protein. ${ }^{40 ; 41}$ Unlike in humans in which MCP has widespread distribution throughout the body, MCP expression in mice is limited to spermatozoa, making its absence in knockout mice of no consequence to renal disease models. ${ }^{42}$ Overall, it is likely that the rodent uses Crry in place of MCP and/or DAF in many sites as its complement regulator, which is not surprising, as Crry combines the functions of both. ${ }^{31}$ In the rodent kidney, this appears to be true in non-glomerular endothelial, mesangial and tubular cells.

$\mathrm{CR} 1$ on human erythrocytes is relevant to IC metabolism, where it binds IC C3b, inactivates it and then facilitates the transfer of $\mathrm{IgG} / \mathrm{iC} 3 \mathrm{~b}$ to $\mathrm{Fc} \gamma$ receptor/CD11b-bearing mononuclear phagocyte cells. ${ }^{43}$ In contrast, rodents use $\mathrm{fH}$ as their C3b-binding fI-cofactor RCA protein, present on platelets, another abundant blood cell (Figure 2a). ${ }^{44}$ Human podocytes have CR1, while rodent podocytes have $\mathrm{fH}$ in its place (Figure $2 \mathrm{~b}$ ). ${ }^{45}$ Studies in rodents have shown platelet and podocyte fH are responsible for systemic and transglomerular IC metabolism, respectively $35 ; 46$, which is consistent with the believed role for CR1 in humans.

\section{HUMAN DISEASES ATTRIBUTABLE TO ABNORMAL COMPLEMENT REGULATION}

The importance of normal complement regulation can be appreciated from the disease paroxysmal nocturnal hemoglobinuria, in which there is impaired GPI linkage of DAF and CD59 to the erythrocyte membrane. ${ }^{47}$ Spontaneous activation of complement through the alternative pathway leads to hemolysis; this now can largely or completely be prevented with eculizumab, a humanized antibody to $\mathrm{C} 5 .{ }^{48}$

An early success with genome-wide association was the linkage of $\mathrm{fH}$ polymorphisms with age-related macular degeneration (ARMD). ${ }^{49-51}$ The importance of $\mathrm{fH}$ to the glomerular capillary wall (GCW) is illustrated by the association of abnormal or absent $\mathrm{fH}$ with atypical hemolytic uremic syndrome (aHUS) and membranoproliferative GN type 2 (also termed dense deposit disease, DDD). The latter is now included in a spectrum of so-called C3 glomerulopathies. This is a rapidly evolving area covered in detail in this issue (Chapters 2 and 3); overall, it is clear mutations conferring gain-of-function to activators and/or loss-offunction to regulators within the complement system can underlie a number of diseases, including those affecting the kidney. $7 ; 52$ 
Complement activation in the renal tubulointerstitium (TI) from excessive activation and/or abnormal regulation appears relevant in a number of disease states. That ammonia-induced $\mathrm{C} 3$ activation could underlie the progression of renal diseases originates from the studies by Nath and Hostetter ${ }^{53}$ this provides theoretical support for the considerable recent interest in correcting acidemia. ${ }^{54}$ Alloantibody-mediated complement activation appears etiologic in humoral renal allograft rejection. Acquired abnormalities of MCP, a complement regulator present in the renal tubulointerstitium ${ }^{37 ; 55}$ may underlie acute kidney injury. ${ }^{56}$ Inherited defects in MCP can clearly lead to aHUS; unlike those due to $\mathrm{fH}$, in these instances, disease does not recur with renal transplantation. ${ }^{57}$

In spite of DAF being present on most endothelia and an effective regulator of the alternative pathway, there is no evidence yet that DAF deficiency or defects are relevant to aHUS, DDD or ARMD. ${ }^{58}$ DAF only displaces $\mathrm{Bb}$ from $\mathrm{C} 3 \mathrm{~b}$; once it moves on, the surfacebound $\mathrm{C} 3 \mathrm{~b}$ remains capable of binding factor $\mathrm{B}$ to again form a $\mathrm{C} 3$ convertase. In contrast, $\mathrm{fH}$ and MCP function to permanently inactivate $\mathrm{C} 3 \mathrm{~b} .{ }^{58 ; 59}$

\section{ANIMAL DISEASE MODELS}

Our understanding of complement regulation in the normal and diseased human kidney has been aided by work in experimental animals. Characterization ("cloning") of human CRPs occurred in the 1970s; the next decade saw identification of CRPs from other species. With this came a number of studies in traditional rat renal disease models using functionneutralizing antibodies. These types of experimental approaches have largely been supplanted by informative studies in mouse strains with targeted gene deletions, which have dominated the past 15 years.

As mentioned earlier, there is compartmentalization of complement regulation in the kidney; $37 ; 55$ in rodents, DAF is on glomerular endothelial cells and podocytes, Crry is on mesangial, non-glomerular endothelial and tubular cells, and $\mathrm{fH}$ is recruited from plasma to the GCW. Perhaps because it is the only cellular regulator of C5b-9, CD59 has a widespread distribution. Since the particular anatomic site within the kidney where complement is activated determines disease phenotype ${ }^{60}$ a range of diseases can occur in the setting of altered CRPs. Experimental animals develop spontaneous disease when either fH or Crry are abnormal or absent; as true in humans, the absence of DAF does not appear to lead to spontaneous disease. Yet, each of the CRPs in the kidney can be relevant in circumstances of heightened complement activation, such as occurs through the classical pathway in ICmediated disease.

\section{MEMBRANOPROLIFERATIVE GLOMERULONEPHRITIS}

The Norwegian group of Jansen, Hogåsen, Mollnes described a heritable porcine model of MPGN type II that led to early mortality. ${ }^{61}$ In a series of biopsies from birth to death they identified C3 and C5b-9 localized within GCW at birth in fetal kidneys without intramembranous deposits or mesangial hypercellularity. Subsequently subendothelial then intramembranous deposits developed, followed by mesangial hypercellularity and expansion associated with development of renal failure. The plasma of these pigs showed very low circulating C3 and highly elevated C5b-9 levels, suggesting unrestricted complement 
activation, potentially due to altered complement regulation. Consistent with this premise, transfusion of normal porcine plasma to affected piglets inhibited complement activation and increased their survival. This group went on to prove disease was attributable to an inherited type 1 defect in $\mathrm{fH}$, such that $\mathrm{fH}$ protein was absent. ${ }^{62}$ These series of studies convincingly showed the absence of $\mathrm{fH}$ was associated with unrestricted complement activation and renal disease akin to human MPGN type II (now known as dense deposit disease, DDD).

Over the eleven years since their initial description of $\mathrm{fH}^{-/-}$mice,${ }^{63}$ the Imperial College group led by Pickering, Botto, and Cook have provided remarkable insights into the pathophysiology of MPGN occurring in these animals. ${ }^{64-68}$ These animals develop a spontaneous inflammatory glomerular disease, histologically containing a mixture of MPGN I and II features, including early complement deposition in GCWs followed later by GCW double contours with mesangial cell interposition, glomerular hypercellularity, and neutrophil influx. ${ }^{63 ; 68}$ Consistent with an alternative pathway mediation, $\mathrm{fH}^{-/-}$mice with a coexistent $\mathrm{fB}$ deficiency are protected from disease. ${ }^{63}$ Spontaneous disease in $\mathrm{fH}^{-/-}$mice requires $\mathrm{C} 5$, but not $\mathrm{C} 6$ activation, supporting a role for $\mathrm{C} 5 \mathrm{a}$ and $\mathrm{C} 5 \mathrm{a}$ receptor activation. ${ }^{68}$

More recent findings in this model include the unexpected improvement of disease with fI absence and worsening with $\mathrm{fP}$ absence. ${ }^{64 ; 67}$ Similar findings to the latter were also noted by Wen-Chao Song's group. ${ }^{69}$ Taking these animal data together, development of MPGN in $\mathrm{fH}^{-/-}$mice requires complement activation and inactivation in the fluid phase to generate iC $3 b$, the latter attributable to fI with other cofactors besides fH. As expected, the absence of fP does impair spontaneous complement activation, but on net, this simply provides more fluid-phase $\mathrm{C} 3$ to feed into nephritic glomeruli.

These studies of the $\mathrm{fH}^{-/}$mouse model have yielded a wealth of information, mainly relevant to MPGN in a general sense. Because of the added role of $\mathrm{fH}$ on mouse platelets and podocytes to process ICs, immunoglobulin accumulates over time in $\mathrm{fH}^{-/}$mouse glomeruli; thus, this is not a true $\mathrm{C} 3$ glomerulopathy, such as DDD. As developed in greater detail in Chapter 2, this distinction is important in humans, as immunoglobulin-positive MPGN will typically have an underlying trigger driving chronic antigenemia or circulating ICs, while (immunoglobulin-negative) $\mathrm{C} 3$ glomerulopathy has been attributed to dysregulated complement activation. Whether all cases of $\mathrm{C} 3$ glomerulopathy are due to abnormal CRPs remains to be established.

\section{IMMUNE COMPLEX-MEDIATED GLOMERULONEPHRITIS}

\section{Chronic serum sickness}

Given its distinctive physiological features, the glomerulus can become involved in ICmediated diseases such as post-infectious GN and lupus nephritis (LN). As a model of circulating IC excess, a number of variations on chronic serum sickness (CSS) have been employed, in which IC deposits accumulate in the mesangium and GCW. ${ }^{70-72}$ Yet, many strains of mice do not develop GN, despite the presence of substantial glomerular IC deposits. ${ }^{73 ; 74}$ Therefore, this is useful to examine whether CRPs are protective in this disease. 
In the rodent glomerulus, Crry is primarily in the mesangium. ${ }^{75}$ Thus, in a mesangial proliferative GN model in rats, blocking Crry worsened disease. ${ }^{76}$ Because maternal C3 deficiency is needed for Crry-deficient fetal survival, ${ }^{77} \mathrm{Crry}^{-/} \mathrm{C}^{+/-}$mice are commonly studied (i.e., providing a wildtype $C 3$ allele of paternal origin). $\mathrm{Crry}^{-/-} \mathrm{C}^{+/-}$mice actively immunized with horse spleen apoferritin had increased development of GN relative to controls, which could be attributed to neutrophil infiltration; absent staining for alphasmooth muscle actin and proliferating cell nuclear antigen suggested that mesangial cell proliferation did not play a significant role in this model. ${ }^{78}$ In comparable studies to examine potential roles for DAF and CD59, both $\mathrm{DAF}^{-/-}$and $\mathrm{DAF}^{-/-} \mathrm{CD} 59^{-/-}$mice had significantly increased glomerular $\mathrm{C} 3$ deposition which correlated with development of GN relative to wildtype controls. ${ }^{79}$ There were no histological or functional disease features in $\mathrm{CD}^{-1-} 9^{--}$or wildtype mice with CSS, which is indirect evidence that C5b-9 has a limited role in this model.

While cellular CRPs appear to limit endocapillary and mesangial IC models of GN, their absence only results in a mild glomerular inflammatory disease. In contrast, fH recruited from the plasma is a critical CRP for the GCW. Thus, all $\mathrm{fH}^{-/}$mice with CSS developed diffuse proliferative GN. ${ }^{80}$ This is well prior to their development of spontaneous glomerular disease, as shown specifically by the inclusion of control $\mathrm{fH}^{-/-}$mice "immunized" with saline, which consistently have normal glomerular histology.

As with spontaneous disease models, studies with $\mathrm{fH}^{-/-}$mice are complicated by the role for $\mathrm{fH}$ in IC processing. Factor $\mathrm{H}^{-/-}$mice with CSS had more glomerular ICs, which could also lead to excessive glomerular complement activation. Because platelet-associated $\mathrm{fH}$ arises intrinsically (i.e., from megakarocytes, Figure 2a) while plasma $\mathrm{fH}$ arises from the liver, they could be separated in mice by generating bone marrow (BM) chimeras between $\mathrm{fH}^{-/}$ and wildtype C57BL/6 mice (Figure 3). ${ }^{35}$ Wildtype mice with $\mathrm{fH}^{-/-} \mathrm{BM}$ lacked platelet $\mathrm{fH}$; thus, systemic IC metabolism was impaired in the CSS model, leading to extensive glomerular deposition of $\mathrm{IgG}$ together with comparable C3. By immunoblotting this C3 was as iC3b. Despite considerable glomerular IgG and iC3b, there was not histopathological (nor functional) GN. In contrast, IC processing in $\mathrm{fH}^{-/-}$mice with wildtype $\mathrm{BM}$ (and $\mathrm{fH}$ on platelets) was similar to wildtype mice, with moderate amounts of glomerular ICs containing $\mathrm{IgG}$ and $\mathrm{C} 3$. Although these mice had less $\mathrm{C} 3 \mathrm{~b}$ and the majority was as $\mathrm{iC} 3 \mathrm{~b}$, there was also active C3b 110-kDa a chain. Despite the lesser quantities of glomerular IgG and total C3, all animals developed GN and thus, IC quality rather than quantity dictate whether inflammation ensues or not. In follow-up studies, the GN occurring in $\mathrm{fH}^{-/-}$mice was $\mathrm{C} 5 \mathrm{aR}$ dependent, as it was prevented in $\mathrm{C}_{5} \mathrm{aR}^{-/-} \mathrm{fH}^{-/-}$mice with CSS (Figure 3f) $; 1$ of note in this figure is the small, but significant increase in BUN in wildtype mice with CSS compared to controls, indicating there is measurable disease expression in CSS in wildtype mice.

Overall, these data support that: 1) Glomerular-bound ICs activate $\mathrm{C} 3$ to C3b, irrespective of complement regulation; 2) While there is considerable $\mathrm{C} 3 \mathrm{~b}$ inactivation in the absence of $\mathrm{fH}$, presumably by $\mathrm{fI}$ and other cofactors, $\mathrm{fH}$ facilitates the inactivation of all $\mathrm{C} 3 \mathrm{~b} ; 3$ ) In the latter case, despite the presence of abundant $\mathrm{IgG}$ and iC $3 \mathrm{~b}$, inflammatory cells bearing $\mathrm{Fc} \gamma$ receptors and $\beta 2$ integrins remain quiescent; 4) Intact $\mathrm{C} 3 \mathrm{~b}$ in ICs is necessary to form an 
active C5 convertase; and, 5) Generation of C5a and signaling through C5aR are necessary events for inflammatory cell activation around glomerular-bound ICs.

\section{Lupus nephritis}

Autoimmune-prone MRL/Mp mice with the lpr gene (due to a retroviral insertion within the Fas/Tnfrsfo gene) develop many features of human systemic lupus erythematosus, including the presence of circulating autoantibodies and consumptive hypocomplementemia. ${ }^{82 ; 83}$ They also develop lupus nephritis (LN) characterized by progressive accumulation of ICs in the GCW and endocapillary proliferative GN. ${ }^{84}$ Thus, this represents an alternative model to CSS to examine complement regulation around glomerular IC deposits.

Factor H-deficient MRL-lpr lupus mice died at a young age, with $2 / 3$ dead by 14 wks of age, compared to none of $\mathrm{fH}^{+/+}$and $\mathrm{fH}^{+/-}$MRL-lpr control animals ${ }^{85}$ Prior to death animals were azotemic (average BUN values of $82.9 \mathrm{mg} / \mathrm{dl}$ within 2 wks of death), consistent with their dying of renal failure. By $12 \mathrm{wks}$ of age, $\mathrm{fH}^{-/-}$MRL-lpr mice developed severe diffuse $\mathrm{LN}$ characterized by mesangial, endocapillary, and extracapillary (i.e., crescentic) cellular proliferation, and hyalinosis lesions in glomeruli representing large subendothelial IC deposits (so called "wire loops" in human LN). Thus, fH deficiency in MRL-lpr mice markedly accelerated renal disease in the 4 wk period between 8 and 12 wks of age. This provides another example of the critical role played by $\mathrm{fH}$ to limit complement activation initiated by ICs within the GCW.

\section{MEMBRANOUS NEPHROPATHY}

Heymann nephritis $(\mathrm{HN})$ is a widely utilized rat model of membranous nephropathy (MN). The fundamental paradigm in HN that antibodies directed towards podocyte antigen(s) progressively accumulate within the subepithelial space appears to have been upheld in human $\mathrm{MN}$; this is then followed by complement activation, C5b-9-mediated podocyte injury and proteinuria (see Chapters 4 and 9, this issue). Active HN depends on the presence of rat IgG2b antibodies, which are efficient at binding $\mathrm{C} 1 \mathrm{q}$ and leading to subsequent complement activation. ${ }^{86} \mathrm{~A}$ similar requirement exists in the passive $\mathrm{HN}$ model for complement-activating sheep $\gamma 1$ anti-Fx1A antibodies. ${ }^{87}$

Podocytes actively regulated complement activation; in the rat, this is attributable to DAF, Crry and CD59. ${ }^{88}$ As true anywhere, for productive complement activation to occur, this regulation must be overcome. ${ }^{89}$ In cultured podocytes, sheep anti-Fx $1 \mathrm{~A}$ antibodies potently activated the alternative pathway, independent of the classical pathway, attributable to impairing complement regulation. ${ }^{90}$ Because the Fx1A antigen preparation used to induce $\mathrm{HN}$ is a crude extract of rat kidney, it was not very surprising to find it contained CRPs. Whether inhibitory anti-CRP antibodies were relevant in HN was investigated. Rats actively immunized with Fx1A depleted of Crry developed glomerular IgG deposits, but these lacked $\mathrm{C} 3$ and animals failed to develop abnormal proteinuria. ${ }^{91}$ Complement activation and proteinuria were restored either by reconstituting the depleted Fx1A preparation with recombinant Crry or by passive administration of anti-Crry $\operatorname{IgG}$ or $\mathrm{F}\left(\mathrm{ab}^{\prime}\right)_{2}$ antibodies. ${ }^{91}$ In a passive model, anti-megalin monoclonal antibodies were "planted" on the rat podocyte in vivo, which activated complement as evidenced by the presence of C3d on podocytes, yet 
did not result in abnormal proteinuria. In this setting, the simultaneous neutralization of Crry and CD59 led to productive complement activation and proteinuria. ${ }^{92}$ However, anti-Fx1A immunodepleted of reactivities towards these CRPs was fully capable of inducing the passive form of $\mathrm{HN}$.

DAF is present on both human and rodent podocytes. ${ }^{39 ; 41}$ In careful histological studies in the rat, DAF is present on the podocyte apical surface, but not the basal surface abutting the GCW. In the puromycin aminonucleoside nephrosis model, DAF-inhibited rats had delayed recovery, consistent with the premise podocyte DAF limits complement activation in glomerular proteinuria. ${ }^{41}$

The conclusions reached from these studies were that Crry, DAF and CD59 are functional on the rat podocyte, where they regulate spontaneous complement activation in proteinuria, and by subepithelial ICs. However, in passive HN, their regulatory capacity is overwhelmed by the tempo of complement activation by podocyte-bound anti-Fx1 A antibodies.

Cultured rat podocytes contain both $\mathrm{fH}$ and $\mathrm{fH}$-related protein $5 .{ }^{45 ; 93}$ The role for $\mathrm{fH}$ in mouse podocytes in vivo was investigated by transplanting kidneys between wildtype and $\mathrm{fH}^{-/-}$mice. ${ }^{46}$ Normal wildtype kidneys in a $\mathrm{fH}^{-/-}$host accumulated $\mathrm{C} 3$ in the mesangium and GCW over several weeks. By immunofluorescence microscopy, these kidneys had prominent $\mathrm{GCW}$ staining for $\mathrm{fH}$, which colocalized with the podocyte marker, a-actinin 4 (Figure 2b). Yet, fH was not present in other renal or extrarenal sites, including sera. In every $\mathrm{fH}^{-/}$recipient of wildtype or $\mathrm{fH}^{-/-}$kidneys in which CSS was induced, diffuse proliferative GN occurred with features identical to those seen in previous studies, affirming the importance of plasma $\mathrm{fH}$ to dictate outcome in this model. Interestingly, $\mathrm{fH}^{-/-}$kidneys in wildtype hosts with CSS had substantial GCW deposits of IgG and C3, which ultrastructurally were present in both subendothelial and subepithelial electron dense deposits. These also had a modest impairment in function (BUN and albuminuria in recipients with bilateral native nephrectomies). The persistence of ICs in subendothelial and subepithelial locations, as well as absent (potential) intrinsic complement regulation by $\mathrm{fH}$ are explanations for these mild phenotypic features. These data supported that $\mathrm{fH}$ was an intrinsic podocyte protein and the kidney does not contribute to systemic fH pools. By analogy to mouse platelet $\mathrm{CfH} /$ human erythrocyte $\mathrm{CR} 1,{ }^{35 ; 44}$ mouse podocytes use $\mathrm{fH}$ in place of CR1.

\section{FOCAL AND SEGMENTAL GLOMERULOSCLEROSIS}

Using passive $\mathrm{HN}$ as a guide, sheep antibodies to cultured mouse podocytes were passively administered to mice. ${ }^{94}$ Given the relevance of DAF on podocytes (discussed above), DAFdeficient mice were also studied. As anticipated, there was deposition of the heterologous sheep IgG on podocytes, followed by mouse (anti-sheep) IgG. Surprisingly, Balb/c DAF ${ }^{-/-}$ mice developed focal and segmental glomerulosclerosis (FSGS), but not MN, within 30 days (Figure 4). In addition to histopathologic FSGS, there were periglomerular collections of Thy $1.2^{+} \mathrm{T}$ and $\mathrm{F} 4 / 80^{+}$mononuclear cells, and mice developed clinical nephrotic syndrome. 
Mice generated an active cellular immune response to heterologous $\operatorname{IgG}$ which was heightened in the global absence of DAF. Consistent with a T cell-mediation, $\mathrm{CD}^{+} \mathrm{T}$ cell depletion 10 and 17 days post-anti-podocyte IgG injection prevented disease. Wildtype Balb/c kidneys transplanted into DAF ${ }^{-/-}$mice developed FSGS (as did native DAFdeficient kidneys), while $\mathrm{DAF}^{-/-}$kidneys in wildtype hosts were protected from FSGS. As such, systemic and not local (e.g., podocyte) DAF deficiency was relevant. In contrast, $\mathrm{Balb}^{\mathrm{nu} / \mathrm{nu}}$ mice reconstituted 4 weeks prior with T cells were susceptible to FSGS only if the $\mathrm{T}$ cell donor was DAF-deficient. These data provide evidence that podocyte-associated antigens can generate an exuberant immune response by DAF-deficient $\mathrm{T}$ cells, leading to podocyte injury and FSGS. ${ }^{94}$

\section{THROMBOTIC MICROANGIOPATHIES}

Nangaku, Johnson, Couser et al generated an experimental model in which direct injection of heterologous anti-glomerular endothelial cells antibodies into the renal artery of rats led to acute renal disease with features of thrombotic thrombocytopenic purpura (TTP) $;{ }^{95}$ this could largely be attributable to C5b-9-induced endothelial cells apoptosis, as it was reduced in the C6-deficient PVG/ $/ \mathrm{c}^{-} \mathrm{rat}^{96}$ and worsened with CD59 inhibition. ${ }^{97}$ In other studies, rats injected with a mouse anti-rat renal endothelial mAb (K6/1, IgG2ak) ${ }^{98}$ developed dosedependent thrombocytopenia, hemolytic anemia, functional acute kidney injury, and histological renal disease including glomerular thrombi and tubular injury. ${ }^{99}$ The renal disease and thrombocytopenia were eliminated if animals were complement depleted with cobra venom factor prior to K6/1 injection, and worsened when the activity of Crry was inhibited with function-neutralizing antibodies. Thus, these are examples of models of thrombotic microangiopathies attributable to anti-endothelial cell antibody-induced complement activation.

The genetic and pathological differences between ARMD, DDD and aHUS, supported the premise the latter alone is attributable to effective plasma $\mathrm{C} 3$ regulation but defective control of complement activation on renal endothelium. To model this, Pickering et al generated transgenic mice exclusively expressing fH protein lacking the terminal five SCR domains $\left(\mathrm{fH}^{-/}\right.$. $\left.\mathrm{fH} \Delta 16-20\right) .{ }^{100}$ These mice had effective complement regulation in the plasma, yet considerably reduced GCW deposition of $\mathrm{C} 3$ products. Mice developed clinical and histopathological features of thrombotic microangiopathy, including renal functional insufficiency and thrombocytopenia. In follow-up studies, a requirement for C5 was shown by comparing C5-sufficient and -deficient strains. ${ }^{101}$ Taken together, these provided evidence that effective regulation of $\mathrm{C} 3$ activation in the fluid-phase but not on surfaces within the GCW, with resultant C5 activation, underlie the pathogenesis of aHUS associated with $f H$ variants.

\section{TUBULOINTERSTITIAL NEPHRITIS}

In normal kidneys, C3 (and C5b-9) staining is evident along the basement membranes of Bowman's capsule and renal tubules ${ }^{74}$ which can be attributed to alternative pathway activation, which is enhanced in warm ischemic-reperfusion injury. ${ }^{53 ; 102}$ Despite the inability to regulate the alternative pathway systemically, unmanipulated $\mathrm{fH}^{-/-}$mice lack 
this typical C3 staining. ${ }^{46}$ Yet, within 30 minutes after being transplanted into a wildtype host, kidneys from fH-deficient mice exhbited small amounts of discontinuous staining for $\mathrm{C} 3$ around tubules and glomeruli. Thus, unlike the GCW, these sites do not appear to recruit systemic $\mathrm{fH}$, with activation of $\mathrm{C} 3$ from the circulation occurring fairly rapidly. From a histological or functional standpoint, this did not appear to be of significance even up to 5 weeks after transplantation.

Clearly Crry is relevant in the TI. This was first shown by Nomura, Matsuo et al with neutralizing antibodies in the rat. ${ }^{103} \mathrm{~A}$ fascinating series of studies from Josh Thurman have shown that the normal polarization of Crry to the basolateral aspect of mouse tubules is lost in ischemia, which leads to unrestricted alternative pathway activation and acute kidney injury upon reperfusion. ${ }^{102 ; 104 ; 105}$ This appears to be relevant to acute kidney injury (tubular necrosis) in humans. ${ }^{56}$

In direct studies to examine complement regulation by Crry in kidneys, kidneys from $\mathrm{Crry}^{-/-} \mathrm{C}^{-/-}$mice were transplanted into complement-sufficient wildtype mice; these developed marked inflammatory cell infiltration, tubular damage and interstitial fibrosis, features absent in control transplanted kidneys. ${ }^{106}$ Strong C3 deposition in the vessels and tubules which correlated significantly with measures of disease supported that complement activation was pathogenic in this model. The functional significance of these pathophysiological findings was evaluated by removing both native kidneys so the transplanted kidney alone provided renal function. Within 21 days of transplantation, over 80 percent of Crry-deficient kidneys in complement-sufficient wildtype hosts failed (leading to fatal azotemia). The inflammatory infiltrate surrounding injured tubuli contained $\mathrm{F} 4 / 80^{+} \mathrm{CD} 11 \mathrm{~b}^{+} \mathrm{Ly} 6 \mathrm{C}(\mathrm{Gr} 1)^{\text {high }}$ and Thy-1.2 $2^{+} \mathrm{T}$ cells, the former characteristic of a classically activated macrophage. To determine the potential roles for extrarenal C3aR and C5aR, $\mathrm{Crry}^{-/-} \mathrm{C}^{-/-}$kidneys were transplanted into wildtype, $\mathrm{C}_{3} \mathrm{aR}^{-/-}$and/or $\mathrm{C} 5 \mathrm{aR}^{-/-}$hosts. All kidneys had marked peritubular $\mathrm{C} 3$ deposition. Only $\mathrm{C}_{3} \mathrm{aR}^{-/-}$hosts were protected from TI nephritis, as determined by pathological criteria and functionally in recipients with bilateral native nephrectomies. Consistent with these disease criteria, TI inflammation with $\mathrm{F} 4 / 80^{+}$ cells and Thy $1.2^{+} \mathrm{T}$ cells assessed by histopathology and flow cytometry was markedly reduced in $\mathrm{C}_{3} \mathrm{aR}^{-/-}$hosts alone. ${ }^{107}$ Thus, acute $\mathrm{C} 3$ activation in Crry-deficient kidneys leads to $\mathrm{C} 3 \mathrm{aR}-$ dependent $\mathrm{TI}$ inflammation with mononuclear phagocytic and $\mathrm{T}$ cells, ultimately culminating in organ scarring and functional renal failure.

\section{CONCLUSIONS}

As a necessary component of immunity towards infectious organisms, activation within the complement cascades leads to generation of injurious and pro-inflammatory proteins. Experimental animals and humans rely on CRPs to protect from unwanted complement activation. Perhaps because of exposure to relatively large quantities of plasma proteins, the endothelial surfaces of the GCW and TI are particularly at risk. Spontaneous alternative pathway activation is regulated by $\mathrm{fH}$. When $\mathrm{fH}$ is ineffective in the fluid phase, there is generation of $\mathrm{iC} 3 \mathrm{~b}$ (by fI) which deposits in the GCW in DDD. Factor $\mathrm{H}$ also is retained by the GCW surface; when this is inefficient, endothelial cell injury and aHUS can result. Similarly, defective cell surface regulation by MCP in humans and Crry in rodents in 
endothelial and epithelial cells of the TI, can result in pathological pictures of aHUS, acute kidney injury and TI nephritis.

If there are initiators of the classical or lectin pathways, such as ICs, the ability of complement regulators to protect "self" tissues is stressed, with the potential for recruitment of the spontaneously active alternative pathway. The threshold for this activation is set by CRPs. Hence, when complement regulation is defective, complement activation and pathological states are more likely to result. Within the endocapillary region of the GCW, fH is key, while DAF and Crry are protective on mesangial cells and podocytes. Acquired alterations in CRPs occur in cellular injury, such as ischemia, or when function blocking auto-antibodies are present, as in the HN models of membranous nephropathy. Besides disease states, altering the level of complement regulation is exploited physiologically to fine tune adaptive immune responses. Overall, the considerable body of experimental work performed by a number of laboratories world-wide has illustrated the important roles for complement activation and its regulation in the normal immune system and in pathological states involving the kidney.

\section{Acknowledgments}

Financial Support: National Institutes of Health grants R01DK41873 and R01DK55357, and a grant-in-aid from the Lupus Foundation of America.

\section{References}

1. Niculescu F, Rus H. Mechanisms of signal transduction activated by sublytic assembly of terminal complement complexes on nucleated cells. Immunol Res. 2001; 24:191-199. [PubMed: 11594456]

2. Bohana-Kashtan O, Ziporen L, Donin N, et al. Cell signals transduced by complement. Mol Immunol. 2004; 41:583-597. [PubMed: 15219997]

3. Cybulsky AV, Quigg RJ, Salant DJ. Experimental membranous nephropathy redux. Am J Physiol Renal, Fluid Electrolyte Physiol. 2005; 289:F660-F671. [PubMed: 16159900]

4. Nonaka M, Kimura A. Genomic view of the evolution of the complement system. Immunogenetics. 2006; 58:701-713. [PubMed: 16896831]

5. Bradley DT, Zipfel PF, Hughes AE. Complement in age-related macular degeneration: a focus on function. Eye (Lond). 2011; 25:683-693. [PubMed: 21394116]

6. Oppermann M, Wurzner R. Modern determination of complement activation. Semin Thromb Hemost. 2010; 36:611-619. [PubMed: 20865637]

7. Heurich M, Martinez-Barricarte R, Francis NJ, et al. Common polymorphisms in C3, factor B, and factor $\mathrm{H}$ collaborate to determine systemic complement activity and disease risk. Proc Natl Acad Sci U S A. 2011; 108:8761-8766. [PubMed: 21555552]

8. Harris CL, Heurich M, de Rodriguez CS, et al. The complotype: dictating risk for inflammation and infection. Trends Immunol. 2012; 33:513-521. [PubMed: 22749446]

9. Sim RB, Twose TM, Paterson DS, et al. The covalent-binding reaction of complement component C3. Biochem J. 1981; 193:115-127. [PubMed: 7305916]

10. Podack ER, Tschopp J. Membrane attack by complement. Mol Immunol. 1984; 21:589-603. [PubMed: 6379417]

11. Morgan, BP.; Harris, CL. Complement Regulatory Proteins. San Diego: Academic Press; 1999. Regulation in the activation pathways; p. 41-136.

12. Alper CA, Rosen FS, Lachmann PJ. Inactivator of the third component of complement as an inhibitor in the properdin pathway. Proc Natl Acad Sci U S A. 1972; 69:2910-2913. [PubMed: 4507613] 
13. Roozendaal R, Carroll MC. Complement receptors CD21 and CD35 in humoral immunity. Immunol Rev. 2007; 219:157-166. [PubMed: 17850488]

14. Lalli PN, Strainic MG, Yang M, et al. Locally produced C5a binds to T cell-expressed C5aR to enhance effector T-cell expansion by limiting antigen-induced apoptosis. Blood. 2008; 112:17591766. [PubMed: 18567839]

15. Lalli PN, Zhou W, Sacks S, et al. Locally produced and activated complement as a mediator of alloreactive T cells. Front Biosci (Schol Ed). 2009; 1:117-124. [PubMed: 19482687]

16. Strainic MG, Liu J, Huang D, et al. Locally produced complement fragments C5a and C3a provide both costimulatory and survival signals to naive CD4+ T cells. Immunity. 2008; 28:425-435. [PubMed: 18328742]

17. Weaver DJ Jr, Reis ES, Pandey MK, et al. C5a receptor-deficient dendritic cells promote induction of Treg and Th17 cells. Eur J Immunol. 2010; 40:710-721. [PubMed: 20017191]

18. Sacks S. Complement fragments C3a and C5a: The salt and pepper of the immune response. Eur J Immunol. 2010; 40:668-670. [PubMed: 20186746]

19. Sacks SH, Zhou W. Allograft rejection: effect of local synthesis of complement. Springer Semin Immunopathol. 2005; 27:332-344. [PubMed: 16189650]

20. Brown KM, Kondeatis E, Vaughan RW, et al. Influence of donor C3 allotype on late renaltransplantation outcome. N Engl J Med. 2006; 354:2014-2023. [PubMed: 16687714]

21. Barlow PN, Baron M, Norman DG, et al. Secondary structure of a complement control protein module by two-dimensional 1H NMR. Biochemistry. 1991; 30:997-1004. [PubMed: 1824927]

22. Barlow PN, Norman DG, Steinkasserer A, et al. Solution structure of the fifth repeat of factor H: A second example of the complement control protein module. Biochemistry. 1992; 31:3626-3634. [PubMed: 1533152]

23. Aslam M, Guthridge JM, Hack BK, et al. The extended multidomain solution structures of the complement protein Crry and its chimeric conjugate Crry-Ig by scattering, analytical ultracentrifugation and constrained modelling: implications for function and therapy. J Mol Biol. 2003; 329:525-550. [PubMed: 12767833]

24. Kristensen T, Wetsel RA, Tack BF. Structural analysis of human complement protein H: homology with C4b binding protein, beta 2-glycoprotein I, and the Ba fragment of B2. J Immunol. 1986; 136:3407-3411. [PubMed: 2937845]

25. Kristensen T, Tack BF. Murine protein H is comprised of 20 repeating units, 61 amino acids in length. Proc Natl Acad Sci U S A. 1986; 83:3963-3967. [PubMed: 2940596]

26. Demberg T, Pollok-Kopp B, Gerke D, et al. Rat complement factor H: molecular cloning, sequencing and quantification with a newly established ELISA. Scand J Immunol. 2002; 56:149_ 160. [PubMed: 12121434]

27. Paul MS, Aegerter M, O'Brien SE, et al. The murine complement receptor gene family. I. Analysis of mCRY gene products and their homology to human CR1. J Immunol. 1989; 142:582-589. [PubMed: 2911011]

28. Molina H, Wong W, Kinoshita T, et al. Distinct receptor and regulatory properties of recombinant mouse complement receptor 1 (CR1) and Crry, the two genetic homologues of human CR1. J Exp Med. 1992; 175:121-129. [PubMed: 1730912]

29. Quigg RJ, Lo CF, Alexander JJ, et al. Molecular characterization of rat Crry: widespread distribution of two alternative forms of Crry mRNA. Immunogenetics. 1995; 42:362-367. [PubMed: 7590969]

30. Harrison RA, Lachmann PJ. The physiological breakdown of the third component of human complement. Mol Immunol. 1980; 17:9-20. [PubMed: 7360115]

31. Kim Y-U, Kinoshita T, Molina H, et al. Mouse complement regulatory protein Crry/p65 uses the specific mechanisms of both human decay-accelerating factor and membrane cofactor protein. $\mathbf{J}$ Exp Med. 1995; 181:151-159. [PubMed: 7528766]

32. Schwaeble W, Zwirner J, Schulz TF, et al. Human complement factor H: expression of an additional truncated gene product of $43 \mathrm{kDa}$ in human liver. Eur J Immunol. 1987; 17:1485-1489. [PubMed: 2445583] 
33. Saland JM, Emre SH, Shneider BL, et al. Favorable long-term outcome after liver-kidney transplant for recurrent hemolytic uremic syndrome associated with a factor $\mathrm{H}$ mutation. Am J Transplant. 2006; 6:1948-1952. [PubMed: 16889549]

34. Vaziri-Sani F, Holmberg L, Sjoholm AG, et al. Phenotypic expression of factor H mutations in patients with atypical hemolytic uremic syndrome. Kidney Int. 2006; 69:981-988. [PubMed: 16528247]

35. Alexander JJ, Aneziokoro OGB, Chang A, et al. Distinct and separable roles of the complement system in factor H-deficient bone marrow chimeric mice with immune complex disease. J Am Soc Nephrol. 2006; 17:1354-1361. [PubMed: 16597679]

36. Endoh M, Yamashina M, Ohi H, et al. Immunohistochemical demonstration of membrane cofactor protein (MCP) of complement in normal and diseased kidney tissues. Clin Exp Immunol. 1993; 94:182-188. [PubMed: 8403504]

37. Ichida S, Yuzawa Y, Okada H, et al. Localization of the complement regulatory proteins in the normal human kidney. Kidney Int. 1994; 46:89-96. [PubMed: 7523758]

38. Cosio FG, Sedmak DD, Mahan JD, et al. Localization of decay accelerating factor in normal and diseased kidneys. Kidney Int. 1989; 36:100-107. [PubMed: 2478749]

39. Quigg RJ, Nicholson-Weller A, Cybulsky AV, et al. Decay accelerating factor regulates complement activation on glomerular epithelial cells. J Immunol. 1989; 142:877-882. [PubMed: 2464030]

40. Lin F, Fukuoka Y, Spicer A, et al. Tissue distribution of products of the mouse decay-accelerating factor (DAF) genes. Exploitation of a Daf1 knock-out mouse and site-specific monoclonal antibodies. Immunology. 2001; 104:215-225. [PubMed: 11683962]

41. Bao L, Spiller OB, St JP, et al. Decay-accelerating factor expression in the rat kidney is restricted to the apical surface of podocytes. Kidney Int. 2002; 62:2010-2021. [PubMed: 12427125]

42. Inoue N, Ikawa M, Nakanishi T, et al. Disruption of mouse CD46 causes an accelerated spontaneous acrosome reaction in sperm. Mol Cell Biol. 2003; 23:2614-2622. [PubMed: 12640142]

43. Hebert LA. The clearance of immune complexes from the circulation of man and other primates. Am J Kidney Dis. 1991; 27:352-361. [PubMed: 1825448]

44. Alexander JJ, Hack BK, Cunningham PN, et al. A protein with characteristics of factor $\mathrm{H}$ is present on rodent platelets and functions as the immune adherence receptor. J Biol Chem. 2001; 276:32129-32135. [PubMed: 11406620]

45. Ren G, Doshi M, Hack BK, et al. Rat glomerular epithelial cells produce and bear factor $\mathrm{H}$ on their surface which is upregulated under complement attack. Kidney Int. 2003; 64:914-922. [PubMed: 12911541]

46. Alexander JJ, Wang Y, Chang A, et al. Mouse podocyte complement factor H - The functional analogue to human complement receptor 1. J Am Soc Nephrol. 2007; 18:1157-1166. [PubMed: 17344423]

47. Parker C. Eculizumab for paroxysmal nocturnal haemoglobinuria. Lancet. 2009; 373:759-767. [PubMed: 19144399]

48. Parker CJ. Paroxysmal nocturnal hemoglobinuria. Curr Opin Hematol. 2012; 19:141-148. [PubMed: 22395662]

49. Haines JL, Hauser MA, Schmidt S, et al. Complement factor H variant increases the risk of agerelated macular degeneration. Science. 2005; 308:419-421. [PubMed: 15761120]

50. Hageman GS, Anderson DH, Johnson LV, et al. A common haplotype in the complement regulatory gene factor $\mathrm{H}(\mathrm{HF} 1 / \mathrm{CFH})$ predisposes individuals to age-related macular degeneration. Proc Natl Acad Sci U S A. 2005; 102:7227-7232. [PubMed: 15870199]

51. Edwards AO, Ritter R III, Abel KJ, et al. Complement factor H polymorphism and age-related macular degeneration. Science. 2005; 308:421-424. [PubMed: 15761121]

52. Pickering MC, Cook HT. Translational mini-review series on complement factor H: renal diseases associated with complement factor $\mathrm{H}$ : novel insights from humans and animals. Clin Exp Immunol. 2008; 151:210-230. [PubMed: 18190458] 
53. Nath KA, Hostetter MK, Hostetter TH. Pathophysiology of chronic tubulo-interstitial disease in rats. Interactions of dietary acid load, ammonia, and complement component C3. J Clin Invest. 1985; 76:667-675. [PubMed: 2993363]

54. Kraut JA, Madias NE. Consequences and therapy of the metabolic acidosis of chronic kidney disease. Pediatr Nephrol. 2011; 26:19-28. [PubMed: 20526632]

55. Funabashi K, Okada N, Matsuo S, et al. Tissue distribution of complement regulatory membrane proteins in rats. Immunology. 1994; 81:444-451. [PubMed: 7515849]

56. Thurman JM, Lucia MS, Ljubanovic D, et al. Acute tubular necrosis is characterized by activation of the alternative pathway of complement. Kidney Int. 2005; 67:524-530. [PubMed: 15673300]

57. Noris M, Caprioli J, Bresin E, et al. Relative role of genetic complement abnormalities in sporadic and familial aHUS and their impact on clinical phenotype. Clin J Am Soc Nephrol. 2010; 5:18441859. [PubMed: 20595690]

58. Liszewski MK, Leung MK, Schraml B, et al. Modeling how CD46 deficiency predisposes to atypical hemolytic uremic syndrome. Mol Immunol. 2007; 44:1570-1579.

59. Harris CL, Pettigrew DM, Lea SM, et al. Decay-accelerating factor must bind both components of the complement alternative pathway C3 convertase to mediate efficient decay. J Immunol. 2007; 178:352-359. [PubMed: 17182573]

60. Salant DJ, Adler S, Darby C, et al. Influence of antigen distribution on the mediation of immunological glomerular injury. Kidney Int. 1985; 27:938-950. [PubMed: 3894765]

61. Jansen JH, Hogåsen K, Mollnes TE. Extensive complement activation in hereditary porcine membranoproliferative glomerulonephritis type II (porcine dense deposit disease). Am J Pathol. 1993; 143:1356-1365. [PubMed: 8238252]

62. Hogasen K, Jansen JH, Mollnes TE, et al. Hereditary porcine membranoproliferative glomerulonephritis type II is caused by factor H deficiency. J Clin Invest. 1995; 95:1054-1061. [PubMed: 7883953]

63. Pickering MC, Cook HT, Warren J, et al. Uncontrolled C3 activation causes membranoproliferative glomerulonephritis in mice deficient in complement factor $\mathrm{H}$. Nat Genet. 2002; 31:424-428. [PubMed: 12091909]

64. Ruseva MM, Vernon KA, Lesher AM, et al. Loss of properdin exacerbates C3 glomerulopathy resulting from factor H deficiency. J Am Soc Nephrol. 2013; 24:43-52. [PubMed: 23184055]

65. Paixao-Cavalcante D, Hanson S, Botto M, et al. Factor $\mathrm{H}$ facilitates the clearance of GBM bound iC3b by controlling C3 activation in fluid phase. Mol Immunol. 2009; 46:1942-1950. [PubMed: 19411110]

66. Fakhouri F, de Jorge EG, Brune F, et al. Treatment with human complement factor H rapidly reverses renal complement deposition in factor H-deficient mice. Kidney Int. 2010; 79:279-286. [PubMed: 20445496]

67. Rose KL, Paixao-Cavalcante D, Fish J, et al. Factor I is required for the development of membranoproliferative glomerulonephritis in factor H-deficient mice. J Clin Invest. 2008; 118:608-618. [PubMed: 18202746]

68. Pickering MC, Warren J, Rose KL, et al. Prevention of C5 activation ameliorates spontaneous and experimental glomerulonephritis in factor H-deficient mice. Proc Natl Acad Sci U S A. 2006; 103:9649-9654. [PubMed: 16769899]

69. Lesher AM, Zhou L, Kimura Y, et al. Combination of factor $\mathrm{H}$ mutation and properdin deficiency causes severe C3 glomerulonephritis. J Am Soc Nephrol. 2013; 24:53-65. [PubMed: 23204401]

70. Stilmant MM, Couser WG, Cotran RS. Experimental glomerulonephritis in the mouse associated with mesangial deposition of autologous ferritin immune complexes. Lab Invest. 1975; 32:746756. [PubMed: 125361]

71. Iskandar SS, Gifford DR, Emancipator SN. Immune complex acute necrotizing glomerulonephritis with progression to diffuse glomerulosclerosis. A murine model. Lab Invest. 1988; 59:772-779. [PubMed: 2974100]

72. Falk RJ, Jennette JC. Immune complex induced glomerular lesions in C5 sufficient and deficient mice. Kidney Int. 1986; 30:678-686. [PubMed: 2946891]

73. Iskandar SS, Jennette JC, Wilkman AS, et al. Interstrain variations in nephritogenicity of heterologous protein in mice. Lab Invest. 1982; 46:344-351. [PubMed: 6460898] 
74. Quigg RJ, Lim A, Haas M, et al. Immune complex glomerulonephritis in C4- and C3-deficient mice. Kidney Int. 1998; 53:320-330. [PubMed: 9461092]

75. Li B, Sallee C, Dehoff M, et al. Mouse Crry/p65: Characterization of monoclonal antibodies and the tissue distribution of a functional homologue of human MCP and DAF. J Immunol. 1993; 151:4295-4305. [PubMed: 7691944]

76. Nishikage H, Baranyi L, Okada H, et al. Role of a complement regulatory protein in rat mesangial glomerulonephritis. J Am Soc Nephrol. 1995; 6:234-242. [PubMed: 7579090]

77. Xu C, Mao D, Holers VM, et al. A critical role for murine complement regulator Crry in fetomaternal tolerance. Science. 2000; 287:498-501. [PubMed: 10642554]

78. Bao L, Wang Y, Chen P, et al. Mesangial cell complement receptor 1-related protein y limits complement-dependent neutrophil accumulation in immune complex glomerulonephritis. Immunology. 2009; 128:e895-e904. [PubMed: 19740350]

79. Bao L, Haas M, Minto AW, et al. Decay-accelerating factor but not CD59 limits experimental immune complex glomerulonephritis. Lab Invest. 2007; 87:357-364. [PubMed: 17259999]

80. Alexander JJ, Pickering MC, Haas M, et al. Complement factor H limits immune complex deposition and prevents inflammation and scarring in glomeruli of mice with chronic serum sickness. J Am Soc Nephrol. 2005; 16:52-57. [PubMed: 15574507]

81. Alexander JJ, Chaves L, Chang A, et al. The C5a receptor has a key role in immune complex glomerulonephritis in complement factor H-deficient mice. Kidney Int. 2012; 82:961-968. [PubMed: 22832515]

82. Andrews BS, Eisenberg RA, Theofilopoulos AN, et al. Spontaneous murine lupus-like syndromes. Clinical and immunopathological manifestations in several strains. J Exp Med. 1978; 148:11981215. [PubMed: 309911]

83. Hahn, BH. Animal models of systemic lupus erythematosus. In: Wallace, DJ.; Hahn, BH., editors. Dubois' Lupus Erythematosus. 6. Baltimore, MD: Williams and Wilkins; 2001. p. 339-388.

84. Bao L, Haas M, Boackle SA, et al. Transgenic expression of a soluble complement inhibitor protects against renal disease and promotes survival in MRL/lpr mice. J Immunol. 2002; 168:3601-3607. [PubMed: 11907125]

85. Bao L, Haas M, Quigg RJ. Complement factor H deficiency accelerates development of lupus nephritis. J Am Soc Nephrol. 2011; 22:285-295. [PubMed: 21148254]

86. Noble B, Van Liew JB, Andres GA, et al. Factors influencing susceptibility of LEW rats to Heymann nephritis. Clin Immunol Immunopathol. 1984; 30:241-254. [PubMed: 6362940]

87. Salant DJ, Belok S, Madaio MP, et al. A new role for complement in experimental membranous nephropathy in rats. J Clin Invest. 1980; 66:1339-1350. [PubMed: 7440718]

88. Quigg RJ, Holers VM, Morgan BP, et al. Crry and CD59 regulate complement in rat glomerular epithelial cells and are inhibited by the nephritogenic antibody of passive Heymann nephritis. J Immunol. 1995; 154:3437-3443. [PubMed: 7534798]

89. Cunningham PN, Quigg RJ. Contrasting roles of complement activation and its regulation in membranous nephropathy. J Am Soc Nephrol. 2005; 16:1214-1222. [PubMed: 15800113]

90. Quigg RJ, Cybulsky AV, Salant DJ. Effect of nephritogenic antibody on complement regulation in cultured rat glomerular epithelial cells. J Immunol. 1991; 147:838-845. [PubMed: 1861077]

91. Schiller B, He C, Salant DJ, et al. Inhibition of complement regulation is key to the pathogenesis of Heymann nephritis. J Exp Med. 1998; 188:1353-1358. [PubMed: 9763614]

92. Cunningham PN, Hack BK, Ren G, et al. Glomerular complement regulation is overwhelmed in passive Heymann nephritis. Kidney Int. 2001; 60:900-909. [PubMed: 11532085]

93. Ren G, Doshi M, Hack BK, et al. Isolation and characterization of a novel rat factor H-related protein that is up-regulated in glomeruli under complement attack. J Biol Chem. 2002; 277:4835148358. [PubMed: 12374811]

94. Bao L, Haas M, Pippin J, et al. Focal and segmental glomerulosclerosis induced in mice lacking decay-accelerating factor in T cells. J Clin Invest. 2009; 119:1264-1274. [PubMed: 19349693]

95. Nangaku M, Alpers CE, Pippin J, et al. A new model of renal microvascular endothelial injury. Kidney Int. 1997; 52:182-194. [PubMed: 9211361] 
96. Hughes J, Nangaku M, Alpers CE, et al. C5b-9 membrane attack complex mediates endothelial cell apoptosis in experimental glomerulonephritis. Am J Physiol Renal Physiol. 2000; 278:F747-757. [PubMed: 10807586]

97. Nangaku M, Alpers CE, Pippin J, et al. CD59 protects glomerular endothelial cells from immunemediated thrombotic microangiopathy in rats. J Am Soc Nephrol. 1998; 9:590-597. [PubMed: 9555661]

98. Mendrick DL, Rennke HG, Cotran RS, et al. Monoclonal antibodies against rat glomerular antigens: production and specificity. Lab Invest. 1983; 49:107-117. [PubMed: 6191120]

99. Ren G, Hack BK, Minto AW, et al. A complement-dependent model of thrombotic thrombocytopenic purpura induced by antibodies reactive with endothelial cells. Clin Immunol. 2002; 103:43-53. [PubMed: 11987984]

100. Pickering MC, de Jorge EG, Martinez-Barricarte R, et al. Spontaneous hemolytic uremic syndrome triggered by complement factor $\mathrm{H}$ lacking surface recognition domains. J Exp Med. 2007; 204:1249-1256. [PubMed: 17517971]

101. de Jorge EG, Macor P, Paixao-Cavalcante D, et al. The development of atypical hemolytic uremic syndrome depends on complement C5. J Am Soc Nephrol. 2011; 22:137-145. [PubMed: 21148255]

102. Thurman JM, Ljubanovic D, Edelstein CL, et al. Lack of a functional alternative complement pathway ameliorates ischemic acute renal failure in mice. J Immunol. 2003; 170:1517-1523. [PubMed: 12538716]

103. Nomura A, Nishikawa K, Yuzawa Y, et al. Tubulointerstitial injury induced in rats by a monoclonal antibody which inhibits function of a membrane inhibitor of complement. J Clin Invest. 1995; 96:2348-2356. [PubMed: 7593622]

104. Thurman JM, Royer PA, Ljubanovic D, et al. Treatment with an inhibitory monoclonal antibody to mouse factor B protects mice from induction of apoptosis and renal ischemia/reperfusion injury. J Am Soc Nephrol. 2006; 17:707-715. [PubMed: 16467447]

105. Thurman JM, Ljubanovic D, Royer PA, et al. Altered renal tubular expression of the complement inhibitor Crry permits complement activation after ischemia/reperfusion. J Clin Invest. 2006; 116:357-368. [PubMed: 16444293]

106. Bao L, Wang Y, Chang A, et al. Unrestricted C3 activation occurs in Crry-deficient kidneys which rapidly leads to chronic renal failure. J Am Soc Nephrol. 2007; 18:811-822. [PubMed: 17229915]

107. Bao L, Wang Y, Haas M, et al. Distinct roles for C3a and C5a in complement-induced tubulointerstitial injury. Kidney Int. 2011; 80:524-534. [PubMed: 21677637] 


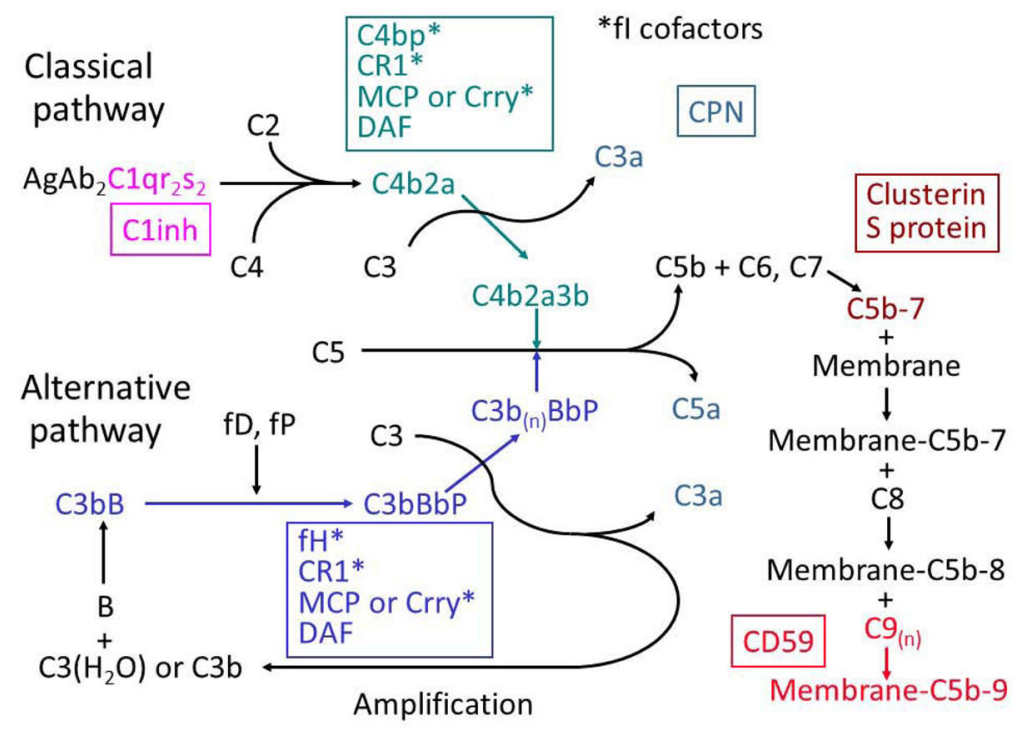

Figure 1. Complement activation and regulation

The proteins relevant to complement activation beginning with ICs in the classical pathway are shown. Regulators of complement activation are in colored boxes adjacent to their site(s) of action. Classical pathway activation can recruit the alternative pathway; if intrinsic regulation is overwhelmed, activation and generation of $\mathrm{C} 3 \mathrm{a}, \mathrm{C} 3 \mathrm{~b}, \mathrm{C} 5 \mathrm{a}$ and $\mathrm{C} 5 \mathrm{~b}-9$ ensues, each of which has pathophysiological relevance in kidney diseases. 
a

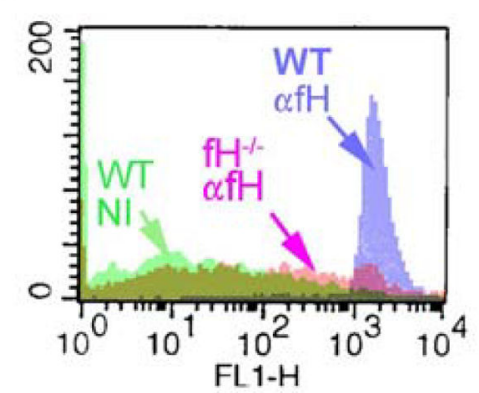

b

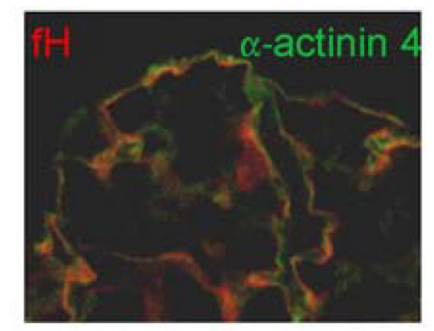

Figure 2. Characteristicization of mouse platelet and podocyte fH

a) Flow cytometric analyses of platelets released from cultured megakaryocytes derived from wildtype (WT) and $\mathrm{fH}^{-/-}$mice. Staining was with specific anti-fH antibodies (afH) or nonimmune (NI) IgG. b) Staining for glomerular fH in a wildtype kidney transplanted into a $\mathrm{fH}^{-/-}$mouse. Staining was also performed for actinin-4 as a podocyte protein, with the merged image shown. 

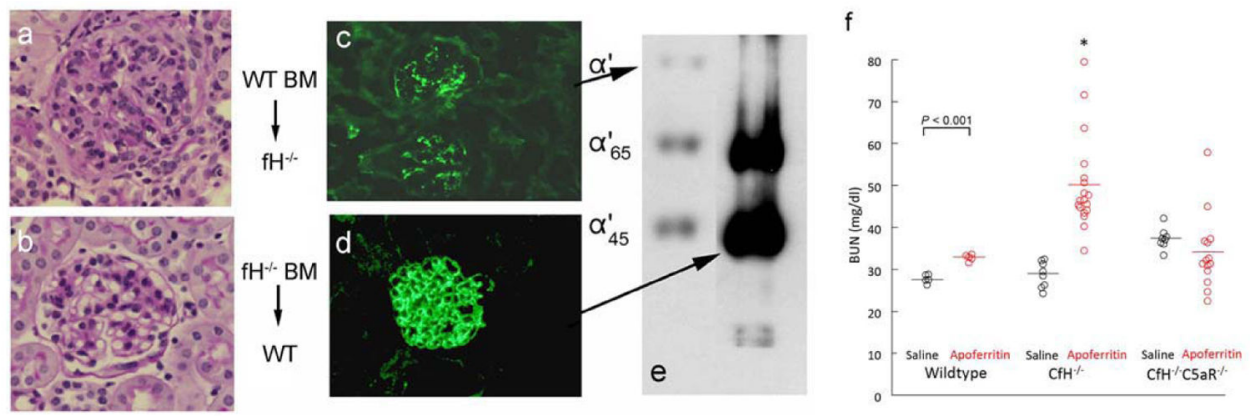

Figure 3. Dependence of experimental GN on plasma $\mathrm{fH}$ and $\mathrm{C5a}$ receptor, and association with C3b in glomerular ICs

a-e) CSS induced in bone marrow (BM) chimeras - $\mathrm{fH}^{-/-}$mice with wildtype BM (a, c) and wildtype mice with $\mathrm{fH}^{-/-} \mathrm{BM}(\mathrm{b}, \mathrm{d})$. Representative glomerular histopathology and immunofluorescence staining are shown. e) Anti-C3 immunoblotting of isolated glomerular proteins. The $\mathrm{C} 3$ a chain generates $\mathrm{C} 3 \mathrm{a}$, and $\mathrm{C} 3 \mathrm{~b}$ with its $110 \mathrm{kDa} \mathrm{a}^{\prime}$ chain; this is cleaved by fI forming $a^{\prime} 65$ and $a^{\prime}{ }_{45}$ chains of inactive (i) C3b. f, BUN values in individual wildtype, $\mathrm{fH}^{-/-}$, and $\mathrm{fH}^{-/-} \mathrm{C}^{-} \mathrm{aR}^{-/-}$mice after 5 wks of daily apoferritin or saline as controls.

ANOVA/Tukey's; *P $<0.001$ vs others. 

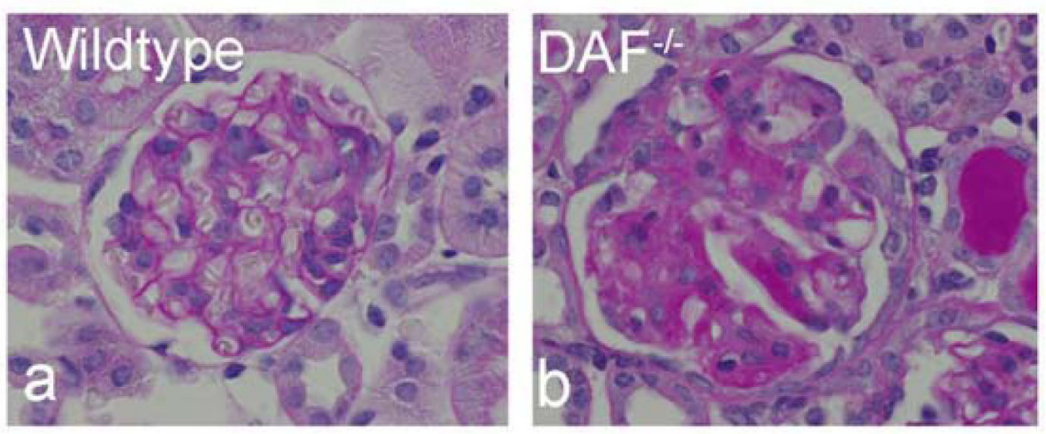

Figure 4. Experimental FSGS

Podocyte injury and segmental glomerulosclerosis occur following injection of antipodocyte antibodies in $\mathrm{DAF}^{-/-}$but not wildtype mice. 